\title{
EVALUASI KAPABILITAS AUDIT INTERNAL PADA PERWAKILAN BPKP PROVINSI KALIMANTAN TIMUR
}

\author{
Efa Agus Susanto \\ Titin Ruliana \\ Imam Nazarudin Latief \\ University of 17 Agustus 1945 Samarinda \\ Jl. Ir. H. Juanda No. 80, 75124, Indonesia \\ imamlatif5@gmail.com
}

\begin{abstract}
This study aims to determine (1) To know the understanding of the enhancement of APIP capability by using Internal Audit Capability Model (IA-CM) (2) To know the internal audit capability level at the BPKP Representative of East Kalimantan Province and the efforts to be taken to improve and maintain it. This research was conducted at BPKP Representative of East Kalimantan Province. Period assessed by the author's internal audit capability is the period of 2016.

This research is conducted by field research and literature research by reading the literature related to the problem under study. The data used to evaluate internal audit capability at BPKP Representative of East Kalimantan Province is data of internal audit capability condition of BPKP Representative of East Kalimantan Province. The analytical tool used in this research is Head of BPKP Regulation No. 16 of 2015 on Technical Guidelines for Capacity Improvement of Government Internal Supervisory Apparatus.

The result of this research is internal audit capability of BPKP Representative of East Kalimantan Province on elements of Role and Service, Professional Practice, Accountability and Performance Management, Organizational Relations and Culture, The Governance Structure is at level 3 (integrated), while the element of Human Resource Management is at level 2 (infrastructure). Based on the evaluation of the six elements, the internal audit capability of BPKP Representative of East Kalimantan Province is at level 3 (integrated) with the record.
\end{abstract}

Keywords: Internal Audit, IA-CM

\section{PENDAHULUAN}

Kapabilitas Aparat Pengawasan

Intern Pemerintah (APIP) yang memadai dengan peran efektif sesuai praktik terbaik yang berlaku secara internasional masih menjadi impian bangsa Indonesia. Pemerintah melalui
Rencana Pembangunan Jangka Menengah Nasional (RPJMN) 20152019 yang dituangkan dalam Peraturan Pemerintah Nomor 2 Tahun 2015, telah menargetkan kapabilitas APIP di tahun 2019 berada pada Level 3 dari skor Level 1-5 sesuai kriteria penilaian internasional. Kapabilitas APIP pada 
level 3 akan mampu untuk menilai efisiensi, efektivitas, dan keekonomisan suatu kegiatan dan mampu memberikan konsultasi pada tata kelola, manajemen risiko, dan pengendalian internal. Namun, kondisi tingkat kapabilitas APIP saat ini sebagian besar $(85,23 \%)$ masih berada pada Level 1. Pada level yang demikian ini terkandung risiko bahwa APIP tidak dapat secara optimal memberikan nilai tambah dari kontribusinya di bidang pengawasan intern bagi keberhasilan penyelenggaraan kegiatan pemerintahan. Penilaian kapabilitas APIP yang sesuai dengan kriteria internasional adalah penilaian kapabilitas yang menggunakan Internal Audit Capability Model (IA-CM). Model ini sudah diakui oleh The Institute of Internal Auditor (IlA) dan dipraktikkan secara internasional. Kapabilitas APIP berdasarkan kriteria penilaian IA-CM dikelompokkan ke dalam lima level, yaitu level 1 (Initial), level 2 (Infrastructure), level 3 (Integrated), level 4 (Managed), dan level 5 (Optimizing). Setiap level terdiri dari enam elemen, yaitu Peran dan Layanan Pengawasan Intern, Pengelolaan SDM, Praktik Profesional, Manajemen dan Akuntabilitas Kinerja, Hubungan dan
Budaya Organisasi, dan Struktur Tata Kelola. Untuk berada sampai level 5 tersebut, APIP harus memenuhi 41 kriteria atau Key Process Area (KPA). KPA merupakan suatu tatanan utama (building blocks) yang menentukan level kapabilitas suatu unit audit internal dan setiap KPA menggambarkan suatu kumpulan kegiatan penting yang terkait yang jika dilaksanakan bersama-sama akan mencapai tujuan (purpose) dan menghasilkan output dalam jangka pendek dan outcome dalam jangka panjang

Sejak diterbitkannya Peraturan Kepala BPKP Nomor 6 Tahun 2015, Perwakilan BPKP Provinsi Kalimantan Timur yang menjadi bagian dari Badan Pengawasan Keuangan dan Pembangunan (BPKP) yang merupakan APIP yang bertanggung jawab langsung kepada Presiden belum melakukan penilaian secara mandiri (self assessment) kapabilitas APIP sesuai kriteria internasional dengan menggunakan 1A-CM. Hal tersebut dikarenakan Kelompok Jabatan Fungsional Auditor Bidang Program dan Pelaporan serta Pembinaan Aparat Pengawasan Internal Pemerintah yang bertugas melaksanakan program dan 
pelaporan serta kegiatan pembinaan APIP baru dibentuk pada tanggal 28 Januari 2016 melalui Perka BPKP Nomor 1 Tahun 2016 tentang Organisasi Dan Tata Kerja Perwakilan Badan Pengawasan Keuangan Dan Pembangunan Provinsi Sumatera Barat, Provinsi Riau, Provinsi Jambi, Provinsi Bengkulu, Provinsi Lampung, Provinsi Kalimantan Barat, Provinsi Kalimantan Timur, Provinsi Kalimantan Selatan, Provinsi Nusa Tenggara Timur, Provinsi Sulawesi Tengah, Provinsi Sulawesi Utara, Provinsi Maluku, dan Provinsi Papua. Penilaian Kapabilitas APIP pada Perwakilan BPKP Provinsi Kalimantan Timur merupakan hal yang sangat penting mengingat kapabilitas BPKP sebagai aparat pengawasan intern berada pada level 3 pada tahun 2019 atau sebelumnya merupakan bagian rencana strategis BPKP tahun 20152019 sebagaimana dituangkan dalam Peraturan Kepala BPKP Nomor 2 Tahun 2015 dan mengingat peran BPKP selaku penjamin kualitas terhadap proses self assessment kapabilitas APIP K/L/Pemerintah Daerah sebagaimana diatur dalam Perka BPKP Nomor 6 Tahun 2015 tentang Grand Design Peningkatan Kapabilitas Aparat Pengawasan Intern Pemerintah.
Berdasarkan uraian latar belakang yang dikemukakan sebelumnya tersebut, perumusan masalah yang akan dibahas dalam penelitian ini adalah "Apakah Kapabilitas Audit Internal pada Perwakilan BPKP Provinsi Kalimantan Timur berada pada level 3 (integrated) penuh atau level 3 (integrated) dengan catatan sebagaimana target BPKP dalam rencana strategis yang dituangkan dalam Peraturan Kepala BPKP Nomor 2 Tahun 2015?”

\section{KERANGKA TEORITIS}

Auditing

Moenaf Regar dalam Suroso (2010:3) juga memberikan pengertian Pemeriksaan (auditing, general audit, financial audit) adalah serangkaian pemeriksaan kegiatan yang bebas dilakukan oleh akuntan untuk meneliti daftar keuangan dari suatu perusahaan yang dilaksanakan menurut norma pemeriksaan akuntan untuk dapat memberikan (atau menolak memberikan) pendapat mengenai kewajaran dari daftar keuangan yang diperiksa.

\section{Audit Internal}

Pengertian audit internal, menurut Tugiman (2006:11): "Suatu fungsi penilaian yang independen yang ada dalam suatu organisasi dengan tujuan 
untuk menguji dan mengevaluasi kegiatan-kegiatan organisasi yang dilaksanakan".

\section{Auditor Internal}

Definisi dari auditor internal seperti yang dikemukakan oleh Mulyadi (2010:29) adalah Auditor internal adalah auditor yang bekerja dalam perusahaan yang tugas pokoknya adalah menentukan apakah kebijakan dan prosedur yang ditetapkan manajemen puncak telah dipatuhi, menentukan baik atau tidaknya penjagaan terhadap kekayaan organisasi, menentukan efisiensi dan efektivitas prosedur kegiatan organisasi, serta menentukan keandalan informasi yang dihasilkan oleh berbagai begian organisasi.

\section{Aparat Pengawasan Instansi Pemerintah (APIP)}

Definisi Aparat Pengawasan Internal Pemerintah (APIP), menurut Peraturan Kepala BPKP Nomor PER1633/K/JF/2011 adalah instansi pemerintah yang dibentuk dengan tugas melaksanakan pengawasan intern (internal audit) di lingkungan pemerintah pusat dan/atau pemerintah daerah, yang terdiri dari Badan Pengawasan Keuangan dan Pembangunan (BPKP), Inspektorat Jenderal Kementerian, Inspektorat/unit pengawasan intern pada Kementerian Negara, Inspektorat Utama/Inspektorat Lembaga Pemerintah Non Kementerian, Inspektorat/unit pengawasan intern pada Kesekretariatan Lembaga Tinggi Negara dan Lembaga Negara, Inspektorat Provinsi/Kabupaten/Kota, dan unit pengawasan intern pada Badan Hukum Pemerintah lainnya sesuai dengan peraturan perundang-undangan.

\section{Kapabilitas APIP}

Pasal 1 Peraturan Kepala BPKP Nomor PER-1633/K/JF/2011, mendefinisikan kapabilitas APIP adalah kemampuan untuk melaksanakan tugas-tugas pengawasan yang terdiri dari tiga unsur yang saling terkait yaitu kapasitas, kewenangan, dan kompetensi SDM APIP yang harus dimiliki APIP agar dapat mewujudkan peran APIP secara efektif.

Internal Audit Capability Model (IACM)

Model Kapabilitas Pengawasan Intern atau Internal Audit Capability Model (IA-CM) menurut BPKP (2011:2 adalah suatu kerangka kerja yang mengindentifikasi aspek-aspek fundamental yang dibutuhkan untuk pengawasan intern yang efektif di sektor publik yang menggambarkan jalur evolusi untuk organisasi sektor 
publik dalam rangka mengembangkan pengawasan intern yang efektif untuk memenuhi persyaratan tata kelola organisasi dan harapan profesional yang menunjukkan langkah-langkah menuju kondisi tingkat kapabilitas pengawasan intern yang kuat dan efektif.

\section{METODOLOGI PENELITIAN}

Penelitian ini dilakukan pada Perwakilan BPKP Provinsi Kalimantan Timur. Variabel yang diteliti sesuai pendekatan IA-CM, yaitu elemen audit internal meliputi peran dan layanan pengelolaan sumber daya manusia, praktik profesional, akuntabilitas dan manajemen kinerja, budaya dan hubungan organisasi, serta struktur tata kelola. Periode yang dinilai kapabilitas audit internalnya oleh penulis adalah periode tahun 2016 .

Alat analisis yang digunakan dalam penelitian ini adalah Peraturan Kepala BPKP Nomor 16 Tahun 2015 tentang Pedoman Teknis Peningkatan Kapabilitas Aparat Pengawasan Intern Pemerintah. Penulis menggunakan pendekatan kualitatif dalam melakukan analisis dengan tahapan sebagai berikut:

1. Analisis Objek

BPKP (2015:12-17) menyebutkan bahwa analisis terhadap objek dilakukan dengan mengumpulkan data dan fakta berdasarkan rincian 151 pernyataan pengukuran kapabilitas APIP terhadap 6 (enam) elemen berikut: (I) Elemen Peran dan Layanan; (II) Elemen Pengelolaan Sumber Daya Manusia; (III) Elemen Praktik Profesional; (IV) Elemen Akuntabilitas dan Manajemen Kinerja; (V) Elemen Hubungan dan Budaya Organisasi; (VI) Elemen Struktur dan Tata Kelola.

2. Penarikan Simpulan

Langkah berikutnya setelah seluruh pernyataan diselesaikan penilaiannya adalah menarik simpulan hasil penilaian. Simpulan dilakukan dengan dua tahap, yaitu:

a. Simpulan Setiap Elemen Kapabilitas, yaitu simpulan yang dilakukan pada setiap level untuk masing-masing enam elemen kapabilitas APIP.

b. Simpulan Umum Seluruh Elemen Kapabilitas, yaitu penarikan simpulan "level" kapabilitas secara umum yang dilakukan setelah level kapabilitas pada tiap-tiap elemen kapabilitas.

\section{ANALISIS DAN PEMBAHASAN}

\section{Analisis}

Alat analisis yang digunakan penulis dalam penelitian ini berupa kuesioner yang membandingkan antara kondisi pada lingkup penelitian dengan 
literatur yang berhubungan dengan penelitian yaitu Peraturan Kepala BPKP Nomor 16 Tahun 2015 tentang Pedoman Teknis Peningkatan Kapabilitas Aparat Pengawasan Intern Pemerintah kemudian menarik kesimpulan dari hasil kuesioner tersebut sehingga bisa ditentukan tingkat kapabilitas audit internalnya.

hasil penelitian dari alat analisis yang digunakan:

Tabel: Capaian Indikator Level Kapabilitas Audit Internal pada Perwakilan BPKP Provinsi Kalimantan Timur

\begin{tabular}{|c|c|c|c|}
\hline \multirow[t]{2}{*}{ Elemen } & \multicolumn{2}{|c|}{$\begin{array}{l}\text { Capaian } \\
\text { Indikator }\end{array}$} & \multirow{2}{*}{\begin{tabular}{|r|} 
Simpul \\
TiaI \\
Ele mi \\
\end{tabular}} \\
\hline & Level 2 & Level 3 & \\
\hline Peran dan Layanan & $9 / 9$ & $10 / 10$ & Level \\
\hline II. $\quad$ Pengelolaan SDM & $12 / 12$ & $17 / 20$ & Level \\
\hline III. Praktik Profesional & $13 / 13$ & $17 / 17$ & Level \\
\hline IV. Akuntabilitas dan Manajemen Kinerja & $10 / 10$ & $19 / 19$ & Level \\
\hline V. Hubungan dan Budaya Organisasi & $6 / 6$ & $14 / 14$ & Level \\
\hline VI. Struktur dan Tata Kelola & $8 / 8$ & $14 / 14$ & Level \\
\hline Subjumlah capaian indikator tiap level & $57 / 57$ & 91/94 & \\
\hline Jumlah capaian indikator s.d. level 3 & \multicolumn{2}{|c|}{$148 / 151$} & \\
\hline \multirow{2}{*}{$\begin{array}{l}\text { Simpulan seluruh elemen kapabilitas audit } \\
\text { internal }\end{array}$} & \multicolumn{3}{|c|}{ "Level 3 (Integrated) } \\
\hline & \multicolumn{3}{|c|}{ dengan Catatan" } \\
\hline
\end{tabular}

Sumber: hasil penelitian,2017

\section{Pembahasan}

1. Hasil Penelitian pada Elemen Peran dan Layanan

Perwakilan BPKP Provinsi

Kalimantan Timur telah memenuhi seluruh KPA elemen peran dan layanan melalui pelaksanaan sembilan belas aktivitas utama dari sembilan belas aktivitas utama yang merupakan indikator capaian sampai dengan level 3 (integrated).

Aktivitas Perwakilan BPKP

Provinsi Kalimantan Timur sepanjang tahun 2016 berdasarkan hasil penelitian meliputi aktivitas audit ketaatan, value for money audit, dan jasa advis (advisory service) sebanyak 167 aktivitas yang dituangkan dalam Program Kerja Pengawasan dan Pembinaan Tahunan (PKP2T) dan telah tercapai secara keseluruhan. Ketiga aktivitas audit internal yang dilaksanakan oleh Perwakilan BPKP Provinsi Kalimantan Timur telah melalui proses perencanaan penugasan dan penyusunan program kerja audit yang diriviu secara berjenjang, mulai dari anggota tim sampai dengan Kepala Perwakilan. Program kerja audit/asistensi juga telah menggambarkan langkah-langkah yang akan dilaksanakan oleh tim pada saat pelaksanaan penugasan di lapangan mulai dari pembicaraan pendahuluan, pelaksanaan audit/asistensi, pembahasan, dan penyusunan laporan serta kertas kerja audit (KKA). Setiap program kerja audit/asistensi memiliki rincian langkah-langkah kerja yang 
berbeda-beda. Hal ini dikarenakan setiap penugasan yang dilaksanakan oleh Perwakilan BPKP Provinsi Kalimantan Timur bersifat spesifik sesuai dengan tujuan dari penugasan itu sendiri baik audit maupun asistensi.

Setiap penugasan yang merupakan aktivitas audit internal yang dilakukan oleh Perwakilan BPKP Provinsi Kalimantan Timur juga telah menghasilkan output berupa laporan dengan jaminan kualitas yang memadai. Laporan dengan jaminan kualitas yang memadai tersebut bisa dicapai karena setiap output/ laporan yang dibuat oleh tim sebagai bentuk komunikasi hasil penugasan pengawasan/asistensi baru akan bisa diterbitkan setelah melalui proses reviu berjenjang mulai dari pengendali teknis, koordinator pengawas, dan Kepala Perwakilan.

Audit yang dilakukan Perwakilan BPKP Provinsi Kalimantan Timur juga telah dapat memberikan keyakinan yang memadai bahwa area/proses/sistem yang diaudit telah sesuai dengan ketentuan pelaksanaannya baik dalam bentuk kebijakan, rencana, prosedur, hukum, peraturan, kontrak maupun kriteria lainnya yang salah satunya dalam bentuk probity audit. Probity audit merupakan kegiatan penilaian secara independen untuk memastikan bahwa proses pengadaan barang/jasa telah dilaksanakan secara konsisten sesuai dengan prinsip penegakan integritas, kebenaran, dan kejujuran dan memenuhi ketentuan perundangan berlaku yang bertujuan meningkatkan akuntabilitas penggunaan dana sektor publik. Kegiatan pengawasan berupa probity audit yang dilakukan Perwakilan BPKP Provinsi Kalimantan Timur pada tahun 2016 adalah probity audit atas penggunaan dana hibah yang berasal dari Pemerintah Provinsi Kalimantan Timur.

Audit ketaatan yang dilakukan Perwakilan BPKP Provinsi Kalimantan Timur telah dapat mencegah dan mendeteksi tindakan ilegal dan penyimpangan terkait dengan kebijakan, prosedur, persyaratan kontrak maupun kriteria lain yang ada. Rekomendasi aktivitas audit internal yang dihasilkan oleh Perwakilan BPKP 
Provinsi Kalimantan Timur sepanjang tahun 2016 sebanyak 167 rekomendasi. Rekomendasi yang telah ditindaklanjuti sebanyak 128 rekomendasi atau sebesar $76,65 \%$. Persentase ini lebih besar dari target indikator kinerja berupa tindak lanjut rekomendasi yang telah ditetapkan Perwakilan BPKP Provinsi Kalimantan Timur sebesar $45 \%$ atau dapat dikatakan capaian kinerja atas tindak lanjut rekomendasi sebesar 170,33\%.

Kegiatan pengawasan yang dilakukan oleh Perwakilan BPKP Provinsi Kalimantan Timur sepanjang tahun 2016 telah mencakup penilaian atas efisiensi, efektivitas, dan kehematan operasi, aktivitas, atau program organisasi di lingkungan wilayah Perwakilan BPKP Provinsi Kalimantan Timur dan hasil-hasil yang telah dicapainya.

Kegiatan pengawasan lain seperti evaluasi, reviu atau pemantauan yang dilakukan oleh Perwakilan BPKP Provinsi Kalimantan Timur juga terkait dengan tata kelola, manajemen risiko, dan pengendalian yang dilakukan dalam rangka peningkatan kualitas governance system di lingkungan wilayah Provinsi Kalimantan Timur. Kegiatan-kegiatan tersebut dilakukan melalui kegiatan assurance dan consulting yang bertujuan untuk meningkatkan kualitas pelaporan keuangan dan kinerja, kapabilitas Aparat Pengawas Intern Pemerintah (APIP) dan menguatkan proses tata kelola pemerintah dan korporasi. Kegiatan-kegiatan tersebut juga telah meningkatkan perbaikan tata kelola, manajemen risiko, dan proses pengendalian yang ditunjukkan salah satunya dengan adanya peningkatan kualitas pelaporan keuangan daerah di wilayah Provinsi Kalimantan Timur. Perwakilan BPKP Provinsi Kalimantan Timur juga telah melakukan penugasan pengawasan berupa pemberian jasa advis tanpa mengambil alih tanggung jawab manajemen. Hal ini terlihat dari laporan hasil pengawasan Perwakilan BPKP Provinsi Kalimantan Timur yang simpulannya merupakan suatu bahan pertimbangan bagi manajemen dalam mengambil keputusan. Simpulan yang 
merupakan suatu bahan

Perwakilan BPKP Provinsi

pertimbangan tersebut bisa dilihat

Kalimantan Timur dilaksanakan

antara lain dalam laporan hasil

audit penyesuaian harga dan

laporan audit klaim. Perwakilan

BPKP Provinsi Kalimantan Timur

juga melaksanakan

penandatanganan dokumen Pakta

Integritas sebagai wujud komitmen

dalam melaksanakan aktivitas audit

internal secara obyektif, profesional,

dan independen.

2. Hasil Penelitian pada Elemen Pengelolaan Sumber Daya Manusia Kapabilitas audit internal Perwakilan BPKP Provinsi

Kalimantan Timur untuk elemen

pengelolaan sumber daya manusia

berada pada level 2 (infrastructure).

Perwakilan BPKP Provinsi

Kalimantan Timur pada awal tahun 2016 didukung dengan SDM sebanyak 122 orang, sedangkan per 31 Desember 2016 mengalami perubahan menjadi 128 orang.

Auditor menempati porsi pegawai paling besar pada Perwakilan BPKP Provinsi Kalimantan Timur, yaitu sebanyak 106 orang dari total seluruh pegawai sebanyak 128 orang atau sebesar $82,82 \%$. Proses rekrutmen dan seleksi auditor pada oleh Tim Rekrutmen dan Seleksi Calon Auditor sehingga nantinya dapat diperoleh auditor yang mempunyai kompetensi baik pengetahuan, keahlian, teknis, maupun sikapnya. Perwakilan BPKP Provinsi Kalimantan Timur juga telah memiliki klasifikasi pemberian tunjangan untuk setiap posisi jabatan yang ditetapkan melalui peraturan presiden. Selain itu, uraian jabatan (job description) di setiap posisi jabatan di Perwakilan BPKP Provinsi Kalimantan Timur juga telah dimiliki.

Perwakilan BPKP Provinsi Kalimantan Timur telah melakukan pengembangan profesi bagi auditor. Hal ini terlihat dari kegiatan diklat yang rutin diselenggarakan untuk peningkatan kompetensi profesional. Jadwal diklat atau training Perwakilan BPKP Provinsi Kalimantan Timur mengacu pada kegiatan-kegiatan diklat yang diselenggarakan oleh Pusat Pendidikan dan Pelatihan Pengawasan (Pusdiklatwas) BPKP yang berada di Ciawi, Bogor. 
Perwakilan BPKP Provinsi

Kalimantan Timur meyakini bahwa

kompetensi auditor baik keahlian, pengetahuan, dan perilaku pada semua posisi telah memadai untuk melaksanakan tugas pokok dan fungsinya. Hal tersebut dibuktikan dengan adanya tercapainya seluruh program kerja pengawasan dan pembinaan tahunan BPKP. Seluruh auditor di Perwakilan BPKP Provinsi Kalimantan Timur telah memiliki sertifikasi di bidang pengawasan internal pemerintah. Perwakilan BPKP Provinsi Kalimantan Timur juga senantiasa mendorong setiap auditornya untuk menjadi anggota profesi dan memenuhi jam pelatihan minimal yang harus dicapai setiap tahun. Hal ini dibuktikan dengan adanya nilai angka kredit yang merupakan kunci kenaikan pangkat auditor atas kedua kegiatan tersebut.

Perwakilan BPKP Provinsi Kalimantan Timur juga memiliki kebijakan yang mendukung adanya koordinasi satgas. Salah satu satgas yang ada di Perwakilan BPKP Provinsi Kalimantan Timur adalah Satgas Pelatihan di Kantor Sendiri (PKS). Satgas PKS merupakan bertugas merencanakan, melaksanakan, melaporkan dan mendokumentasikan kegiatan PKS yang merupakan salah satu media yang bisa menjadi tempat bagi auditor untuk meningkatkan kompetensinya.

Perwakilan BPKP Provinsi Kalimantan Timur telah mengestimasi jumlah dan ruang lingkup kegiatan audit dan kegiatan pengawasan lainnya dan membandingkan dengan jumlah dan keahlian SDM yang tersedia. Hal ini dibuktikan terlihat dari empat sasaran program yang telah dilaksanakan oleh Perwakilan BPKP Provinsi Kalimantan Timur, hanya satu sasaran program saja yang penggunaan sumber daya manusianya tidak efisien.

Perwakilan BPKP Provinsi Kalimantan Timur juga telah mempunyai staf APIP yang berkualifikasi profesional. Perwakilan BPKP juga memelihara kualifikasi profesional setiap staf APIP melalui penilaian prestasi kinerja. Penilaian prestasi kerja merupakan proses manajemen kinerja yang berawal dari penyusunan perencanaan prestasi 
kerja berupa Sasaran Kerja Pegawai (SKP), penetapan tolok ukur yang meliputi aspek kuantitas, kualitas, waktu, dan biaya dari setiap kegiatan tugas jabatan. Analisis dan evaluasi juga dilakukan dalam proses penilaian apabila ditemukan hambatan pelaksanaan pekerjaan untuk mendapatkan umpan balik, menyusun rekomendasi perbaikan serta menetapkan hasil penilaian prestasi kerja pegawai.

Perwakilan BPKP Provinsi Kalimantan Timur sangat mengutamakan adanya kompetensi dan team building dalam menjalankan aktivitas audit internalnya. Team building pada Perwakilan BPKP Provinsi Kalimantan Timur terlihat dari adanya mekanisme komunikasi dan koordinasi tim audit. Komunikasi dan koordinasi tim audit dilaksanakan sesuai dengan standar kendali mutu audit internal dan diterapkan pada setiap tahapan perencanaan, pelaksanaan, dan pelaporan penugasan tim audit. Perwakilan BPKP Provinsi Kalimantan Timur juga secara rutin melaksanakan program pengembangan tim setiap tahun yang diselenggarakan oleh Bagian Tata Usaha. Selain itu, Perwakilan BPKP Provinsi Kalimantan Timur juga memberikan wadah bagi timtim untuk saling berbagi pengetahuan dan pengalaman melalui kegiatan Pelatihan di Kantor Sendiri (PKS) atau Program Pelatihan Mandiri (PPM). Namun, Perwakilan BPKP Provinsi Kalimantan Timur juga masih memiliki kelemahan dalam pelaksanaan kapabilitas audit internal pada elemen pengelolaan sumber daya manusia ini, yaitu:

a. Perwakilan BPKP Provinsi Kalimantan Timur belum memiliki mekanisme pemberian reward /penghargaan bagi pegawai yang berkinerja memuaskan atau terbaik pada setiap tingkatan.

b. Perwakilan BPKP Provinsi Kalimantan Timur belum memiliki sistem pengembangan karir (promosi, rotasi, dan mutasi) dengan membandingkan kinerja auditor dengan kinerja yang diharapkan.

c. Perwakilan BPKP Provinsi Kalimantan Timur belum 
memiliki mekanisme pemberian penghargaan bagi tim yang berhasil menerapkan perilaku yang diharapkan.

3. Hasil Penelitian Pada Elemen Praktik Profesional

Perwakilan BPKP Provinsi Kalimantan Timur telah memenuhi seluruh KPA elemen praktik profesional melalui pelaksanaan tiga puluh aktivitas utama dari tiga puluh aktivitas utama yang merupakan indikator capaian sampai dengan level 3 (integrated).

Perencanaan pengawasan Perwakilan BPKP Provinsi Kalimantan Timur telah disusun berdasarkan pada prioritas manajemen atau pemangku kepentingan. Perwakilan BPKP Provinsi Kalimantan Timur selaku Auditor Presiden sepanjang tahun 2016 telah merencanakan dan melaksanakan kegiatan-kegiatan yang mendukung program pemerintah dengan melakukan pengawasan terhadap pelaksanaan program-program strategis yang tertuang dalam program Nawacita. Perwakilan BPKP Provinsi Kalimantan Timur memiliki kerangka kerja praktik profesional berikut prosesnya. Kerangka kerja praktik profesional yang dimiliki Perwakilan BPKP Provinsi Kalimantan Timur mengacu pada Standar Audit Intern Pemerintah Indonesia (SAIPI) yang berfungsi sebagai ukuran mutu minimal bagi para auditor dan pimpinan Perwakilan BPKP Provinsi Kalimantan Timur.

Perwakilan BPKP Provinsi Kalimantan Timur juga melakukan penilaian risiko saat perencanaan aktivitas audit internal. Penilaian risiko tersebut ditunjukkan dengan adanya proses telaah yang dilakukan oleh auditor sebelum penerbitan surat tugas. Perwakilan BPKP Provinsi Kalimantan Timur juga memiliki kerangka kerja untuk mengelola kualitas hasil audit internal. Hal ini dibuktikan dengan adanya proses riviu/quality assurance yang dilakukan dalam proses penyusunan laporan hasil pengawasan audit internal mulai dari pengendali teknis, koordinator pengawas, dan kepala perwakilan. Beberapa laporan tertentu khususnya laporan hasil pengawasan audit internal yang dilakukan oleh bidang pengawasan 
investigasi, proses riviunya dilakukan mulai dari pengendali teknis, koordinator pengawas, kepala perwakilan, dan tim perencanaan pengendalian yang berada di Kantor BPKP Pusat.

4. Hasil Penelitian pada Elemen Akuntabilitas dan Manajemen Kinerja

Perwakilan BPKP Provinsi

Kalimantan Timur telah memenuhi seluruh KPA elemen akuntabilitas dan manajemen kinerja melalui pelaksanaan dua puluh sembilan aktivitas utama dari dua puluh sembilan aktivitas utama yang merupakan indikator capaian sampai dengan level 3 (integrated). Perwakilan BPKP Provinsi Kalimantan Timur sepanjang tahun 2016 berdasarkan hasil penelitian memiliki rencana aktivitas audit internal yang meliputi aktivitas audit ketaatan, value for money audit, dan jasa advis (advisory service) sebanyak 167 aktivitas yang dituangkan dalam Program Kerja Pengawasan dan Pembinaan Tahunan (PKP2T). Setiap rencana aktivitas audit internal yang dilakukan oleh Perwakilan BPKP Provinsi Kalimantan Timur selama tahun 2016 juga telah didukung oleh anggaran operasional. Anggaran tersebut disusun secara realistis/ wajar dan dilakukan riviu secara berkesinambungan untuk memastikan bahwa anggaran yang disusun masih realistis dan akurat.

Perwakilan BPKP Provinsi Kalimantan Timur setiap tahun menyusun laporan manajemen kegiatan pengawasan dalam bentuk Laporan Akuntabilitas Kinerja sebagai wujud pertanggungjawaban dan akuntabilitas manajemen bahwa kegiatan pengawasan intern telah dapat dipenuhi. Laporan Kinerja ini membandingkan realisasi kinerja Perwakilan BPKP Provinsi Kalimantan Timur Tahun 2016 dengan Penetapan Kinerja Tahun 2016.

Perwakilan BPKP Provinsi Kalimantan Timur memiliki sistem informasi biaya untuk melaksanakan kegiatan pengawasan sehingga dapat dilakukan pemantauan biaya yang sebenarnya dibandingkan dengan biaya standar atau biaya yang telah ditetapkan pada berbagai tahap kegiatan pengawasan intern. 
Salah satu penerapan sistem informasi biaya yang dilakukan oleh Perwakilan BPKP Provinsi Kalimantan Timur ditunjukkan dengan adanya dokumen cost sheet yang dilampirkan dalam setiap pengajuan penugasan. Dokumen cost sheet tersebut berisi rincian rencana biaya yang dibutuhkan oleh auditor sebelum melaksanakan kegiatan audit internal. Dokumen cost sheet juga menginformasikan jumlah anggaran yang tersedia untuk penugasan terkait sehingga dapat menjadi dasar bagi pimpinan untuk mengambil keputusan dengan tetap mempertimbangkan pengen-dalian biaya.

Sistem pengendalian biaya pada Perwakilan BPKP Provinsi Kalimantan Timur juga telah berjalan dengan baik. Hal ini ditunjukkan dengan adanya efisiensi yang dicapai oleh Perwakilan BPKP Provinsi Kalimantan Timur untuk melaksanakan keseluruhan 167 aktivitas audit internal dengan persentase realisasi biaya sebesar 91,99\%. Pengukuran kinerja pada Perwakilan BPKP Provinsi Kalimantan dilakukan berdasarkan pada perjanjian kinerja yang ditetapkan setiap tahun. Perjanjian kinerja itu sendiri merupakan bentuk kesanggupan dari Perwakilan BPKP Provinsi Kalimantan Timur untuk mewujudkan target kinerja tahunan dan mempertanggungjawabkan keberhasilan maupun kegagalan-nya

5. Hasil Penelitian pada Elemen Hubungan dan Budaya Organisasi

Perwakilan BPKP Provinsi Kalimantan Timur telah memenuhi seluruh KPA elemen hubungan dan budaya organisasi melalui pelaksanaan dua puluh aktivitas utama dari dua puluh aktivitas utama yang merupakan indikator capaian sampai dengan level 3 (integrated). Perwakilan BPKP Provinsi Kalimantan Timur telah memiliki pengelolaan atas aktivitas pengawasan intern yang menggunakan perangkat berbasis website yang bisa diakses melalui alamat laman http://app.bpkp.go.id Struktur organisasi Perwakilan BPKP Provinsi Kalimantan Timur untuk melaksanakan pengawasan intern telah sesuai dengan sesuai peraturan yang berlaku yang ditetapkan secara formal melalui 
Peraturan Kepala BPKP. Kepala BPKP juga telah mengidentifikasikan peran dan tanggung jawab seluruh pejabat struktural di lingkungan Perwakilan BPKP Provinsi Kalimantan Timur. Hubungan dan komunikasi pada tingkat lingkungan internal Perwakilan BPKP Provinsi Kalimantan Timur terjalin cukup efektif dan memiliki aturan, arahan, dan sarana komunikasi yang memadai. Komunikasi internal dilakukan secara berkala melalui rapat-rapat internal ataupun melalui forum-forum komunikasi antar seluruh elemen dalam unit organisasi. Hal tersebut penting dilakukan untuk meningkatkan koordinasi dalam rangka mencapai target kinerja dan menyelesaikan kegiatan audit internal yang telah ditetapkan sebelumnya.

Perwakilan BPKP Provinsi Kalimantan Timur bersama-sama dengan unit Perwakilan lain dalam organisasi BPKP merupakan satu tim manajemen. Hal ini terlihat dari hubungan dan komunikasi pada tingkat antar Perwakilan juga berjalan baik. Perwakilan BPKP Provinsi Kalimantan Timur turut terlibat secara aktif dan partisipatif dalam kegiatan BPKP Pusat untuk mengetahui perkembangan strategis dan operasional kegiatan pengawasan intern. Peningkatan hubungan dan komunikasi di lingkungan internal Perwakilan BPKP Provinsi Kalimantan Timur, dilakukan melalui penyelenggaraan rapat-rapat internal dan forumforum komunikasi antara seluruh elemen dalam unit organisasi, baik pimpinan maupun seluruh pegawai. Perwakilan BPKP Provinsi Kalimantan Timur juga telah bersinergi dengan aparat pengawasan intern pemerintah dalam pengawasan lintas sektoral dan mitra pemerintah dalam tindak lanjut perbaikan manajemen hasil pemeriksaan BPK. Kegiatan pengawasan Perwakilan BPKP Provinsi Kalimantan Timur juga menghasilkan rekomendasi positif kepada pimpinan satuan kerja di Provinsi Kalimantan Timur sehingga dapat mewujudkan hubungan yang semakin harmonis dan efektif antara Perwakilan BPKP Provinsi Kalimantan Timur dengan mitra kerjanya. 
Perwakilan BPKP Provinsi

Kalimantan Timur dalam hal pemberian jasa advis dan penjaminan (other review groups) telah diwujudkan dengan cara menjalin hubungan dan komunikasi secara kooperatif dan transparan, baik secara formal maupun non formal dengan auditor eksternal seperti Perwakilan BPK Provinsi Kalimantan Timur ataupun APIP lainnya. Perwakilan BPKP Provinsi Kalimantan Timur juga berperan sebagai penghubung/ mewakili BPKP dalam berkoordinasi dengan auditor eksternal, terutama sebagai tim counterpart dalam mendampingi tim audit eksternal menjalankan pemeriksaan/ pengawasan di Provinsi Kalimantan Timur yang merupakan area kerjanya. Perwakilan BPKP Provinsi Kalimantan Timur juga berperan mereviu draft hasil temuan dari auditor eksternal sebagai tanggapan auditan mewakili BPKP untuk wilayah Provinsi Kalimantan Timur sehingga temuan yang disepakati telah sesuai dengan kondisi yang ada. Temuan hasil pemeriksaan/ pengawasan yang telah final maka akan segera ditindaklanjuti. Perwakilan BPKP Provinsi Kalimantan Timur akan melakukan koordinasi tindak lanjut hasil temuan tersebut, sehingga dapat segera diselesaikan. Perwakilan BPKP Provinsi Kalimantan Timur juga mendorong auditor eksternal untuk senantiasa memanfaatkan hasil audit internal, dengan berbagi rencana kerja dan memberikan data/ informasi hasil audit yang telah dilakukan oleh Perwakilan BPKP Provinsi Kalimantan Timur yang dibutuhkan audit eksternal sehingga tidak terjadi tumpang tindih pemeriksaan. Hubungan dengan pihak auditor eksternal juga terjalin dengan baik, diantaranya dengan menghadiri undanganundangan yang diselenggarakan oleh auditor ekseternal ataupun menerima kunjungan dari APIP lainnya yang ingin berbagi pengetahuan dan pengalaman dalam bidang audit internal.

6. Hasil Penelitian pada Elemen Struktur dan Tata Kelola

Perwakilan BPKP Provinsi Kalimantan Timur telah memenuhi seluruh KPA elemen struktur dan tata kelola melalui pelaksanaan dua 
puluh satu aktivitas utama dari dua puluh satu aktivitas utama yang merupakan indikator capaian sampai dengan level 3 (integrated). Elemen struktur tata kelola ini sangat ditentukan oleh komitmen dari luar fungsi audit internal. Hubungan pelaporan yang telah terbangun terlihat dari komitmen yang tinggi dari Kepala BPKP selaku pimpinan tertinggi BPKP untuk mendorong penguatan independensi, obyektivitas, dan efektivitas Perwakilan BPKP Provinsi Kalimantan Timur. Perwakilan BPKP Provinsi Kalimantan Timur secara formal telah memiliki tugas dan fungsi sesuai dengan Peraturan Kepala BPKP Nomor 1 Tahun 2016 tentang Organisasi dan Tata Kerja Perwakilan. Dokumen Rencana Strategis juga telah mencantumkan visi, misi, tujuan, dan sasaran Perwakilan BPKP Provinsi Kalimantan Timur. Komitmen tersebut juga diperkuat melalui Peraturan Presiden Nomor 192 Tahun 2014 tentang BPKP sebagai wujud komitmen formal yang memberikan kerangka kerja bagi berjalannya fungsi audit internal mengingat kedudukan BPKP selaku Auditor Presiden.

Perwakilan BPKP Provinsi

Kalimantan Timur secara aktif berupaya mendorong jajaran pimpinan di wilayah kerjanya untuk mendukung independensi Perwakilan BPKP Provinsi Kalimantan Timur melalui usahausaha seperti mengomunikasikan mandat, kewenangan, independensi, dan manfaat kegiatan pengawasan intern ke seluruh organisasi. Perwakilan BPKP Provinsi Kalimantan Timur juga memberikan laporan secara fungsional dan administratif kepada BPKP Pusat sebagai wujud pertanggungjawaban dalam menjalankan tugas dan fungsi yang diamanatkan kepada Perwakilan BPKP Provinsi Kalimantan Timur dalam hal tata kelola pelaporan.

Perwakilan BPKP Provinsi Kalimantan Timur memiliki akses penuh terhadap informasi, aset, dan personil unit organisasi di lingkungan kerjanya. Akses tersebut sangat diperlukan dalam kegiatan peningkatan good governance systemn yang 
dilakukan Perwakilan BPKP

Provinsi Kalimantan Timur.

Anggaran yang dimiliki Perwakilan

BPKP Provinsi Kalimantan telah mencakup anggaran yang diperlukan untuk melaksanakan aktivitas audit internal. Hal ini terlihat dari terlaksananya 167 aktivititas audit internal dari 167 aktivitas audit internal yang direncanakan sepanjang tahun 2016. Perwakilan BPKP Provinsi Kalimantan Timur juga telah memiliki mekanisme koordinasi dengan pihak lain yang memberikan jasa penjaminan (assurance) dan pemberian saran (advisory services) bagi organisasi di wilayah kerjanya, sehingga koordinasi kegiatan terlaksana dan informasi dan hasil kerja Perwakilan BPKP Provinsi Kalimantan Timur dapat dibagikan secara langsung terhadap instansiinstansi tersebut. Tata kelola yang baik biasanya terdapat proses pengawasan yang independen terhadap kinerja dari suatu instansi termasuk Perwakilan BPKP Provinsi Kalimantan Timur. Pengawasan secara independen terhadap kinerja Perwakilan BPKP
Provinsi Kalimantan Timur saat ini dilakukan oleh Inspektorat BPKP yang berkedudukan di Jakarta.

Dari hasil analisis dan pembahasan evaluasi kapabilitas audit internal pada Perwakilan BPKP Provinsi Kalimantan Timur yang dikemukakan sebelumnya, diperoleh simpulan bahwa kapabilitas audit internal pada Perwakilan BPKP Provinsi Kalimantan Timur berada pada level 3 dengan catatan sehingga dengan demikian hipotesis diterima.

\section{KESIMPULAN}

Berdasarkan analisis dan pembahasan yang telah dikemukakan sebelumnya, dapat disimpulkan sebagaimana berikut:

1. Kapabilitas audit internal Perwakilan BPKP Provinsi Kalimantan Timur pada elemen Peran dan Layanan berada pada level 3 (integrated) yang berarti bahwa peranan dan layanan yang diberikan Perwakilan BPKP Provinsi Kalimantan Timur yaitu berupa audit ketaatan, value for money audit atau audit kinerja, dan jasa advis (advisory service).

2. Kapabilitas audit internal Perwakilan BPKP Provinsi Kalimantan Timur pada elemen 
Pengelolaan Sumber Daya Manusia berada pada level 2 (infratsructure). Namun, Perwakilan BPKP juga telah memenuhi sebagian KPA kapabalitas audit internal elemen pengelolaan sumber daya manusia untuk mencapai level 3 (integrated). Capaian KPA kapabilitas audit internal yang telah dilaksanakan secara keseluruhan aktivitas utamanya oleh Perwakilan BPKP Provinsi Kalimantan Timur, yaitu:

a. Perwakilan BPKP Provinsi Kalimantan Timur mengidentifikasi dan merekrut orangorang yang kompeten;

b. Perwakilan BPKP Provinsi Kalimantan Timur telah melakukan pengembangan profesi bagi individu auditor;

c. Adanya koordinasi satuan tugas sumber daya manusia pada Perwakilan BPKP Provinsi Kalimantan Timur.

Capaian KPA kapabilitas audit internal yang belum dilaksanakan secara keseluruhan aktivitas utamanya oleh Perwakilan BPKP Provinsi Kalimantan Timur, yaitu:

a. Tersedianya staf pada Perwakilan BPKP Provinsi
Kalimantan Timur yang berkualifikasi profesional.

b. Adanya kompetensi dan team building.

3. Kapabilitas audit internal Perwakilan BPKP Provinsi Kalimantan Timur pada elemen Praktik Profesional berada pada level 3 (integrated) yang berarti bahwa:

a. Perencanaan pengawasan disusun berdasarkan pada prioritas manajemen/ pemangku kepentingan;

b. Perwakilan BPKP Provinsi Kalimantan Timur memiliki kerangka kerja praktik profesional berikut prosesnya;

c. Perwakilan BPKP Provinsi Kalimantan Timur memiliki perencanaan audit berbasis risiko;

d. Perwakilan BPKP Provinsi Kalimantan Timur memiliki kerangka kerja untuk mengelola kualitas.

4. Kapabilitas audit internal Perwakilan BPKP Provinsi Kalimantan Timur pada elemen Akuntabilitas dan Manajemen Kinerja berada pada level 3 (integrated) yang berarti bahwa: 
a. Perwakilan BPKP Provinsi

Kalimantan Timur memiliki

perencanaan kegiatan

pengawasan;

b. Perwakilan BPKP Provinsi

Kalimantan Timur memiliki

anggaran operasional kegiatan pengawasan;

c. Perwakilan BPKP Provinsi

Kalimantan Timur membuat

laporan manajemen kegiatan pengawasan;

d. Perwakilan BPKP Provinsi Kalimantan Timur memiliki informasi mengenai keuang-an;

e. Perwakilan BPKP Provinsi Kalimantan Timur mempunyai sistem peng-ukuran kinerja.

5. Kapabilitas audit internal Perwakilan BPKP Provinsi Kalimantan Timur pada elemen Budaya dan Hubungan Organisasi berada pada level 3 (integrated) yang berarti bahwa:

a. Perwakilan BPKP Provinsi Kalimantan Timur memiliki pengelolaan atas bussiness process pengawasan intern;

b. Perwakilan BPKP Provinsi Kalimantan Timur APIP bersama-sama dengan unit lain dalam organisasi merupakan satu tim manajemen;

c. Perwakilan BPKP Provinsi Kalimantan Timur berkoodinasi dengan pihak lain yang menyediakan jasa pemberian advis dan penjaminan.

6. Kapabilitas audit internal Perwakilan BPKP Provinsi Kalimantan Timur pada elemen Struktur dan Tata Kelola berada pada level 3 (integrated) yang berarti bahwa:

a. Hubungan pelaporan pada Perwakilan BPKP Provinsi Kalimantan Timur telah terbangun;

b. Perwakilan BPKP Provinsi Kalimantan Timur memiliki akses penuh terhadap informasi dan personil unit organisasi;

c. Perwakilan BPKP Provinsi Kalimantan Timur memiliki mekanisme penganggaran kegiatan pengawasan;

d. Adanya pengawasan terhadap pelaksanaan kegiatan Perwakilan BPKP Provinsi Kalimantan Timur oleh manajemen BPKP Pusat.

7. Kapabilitas audit internal Perwakilan BPKP Provinsi 
Kalimantan Timur secara umum berdasarkan capaian keenam elemen sebelumnya, dapat disimpulkan bahwa kapabilitas audit internal Perwakilan BPKP Provinsi Kalimantan Timur adalah "level 3 (integrated) dengan catatan" sehingga hipotesis diterima.

\section{Daftar Pustaka}

Anonim,BPKP.2011.Peraturan Kepala BPKP Tentang Pedoman Teknis Peningkatan Kapabilitas APIP. Jakarta:BPKP.

2015.Peraturan Kepala BPKP Nomor 2 Tahun 2015 Tentang Rencana Strategis BPKP 2015 2019.Jakarta:BPKP.

2015.Peraturan Kepala BPKP Nomor 6 Tahun 2015 Tentang Grand Design Peningkatan Kapabilitas APIP 2015 - 2019. Jakarta: BPKP.

2015.Pedoman Teknis Penilaian Mandiri Kapabilitas APIP. Jakarta:BPKP.

\section{Pedoman}

Teknis

Penjaminan Kualitas Penilaian Mandiri Kapabilitas APIP. Jakarta: BPKP.

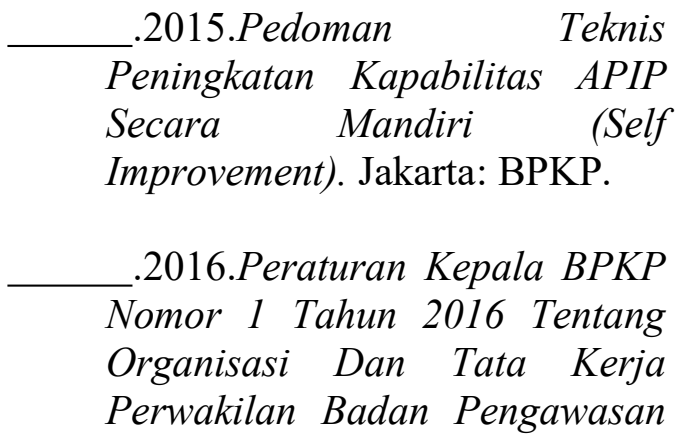

Keuangan Dan Pembangunan Provinsi Sumatera Barat, Provinsi Riau, Provinsi Jambi, Provinsi Bengkulu, Provinsi Lampung, Provinsi Kalimantan Barat, Provinsi Kalimantan Timur, Provinsi Kalimantan Selatan, Provinsi Nusa Tenggara Timur, Provinsi Sulawesi Tengah, Provinsi Sulawesi Utara, Provinsi Maluku, dan Provinsi Papua. Jakarta: BPKP.

.Perwakilan BPKP Provinsi Kalimantan Timur.2017. Laporan Akuntabilitas Kinerja Perwakilan BPKP Provinsi Kalimantan Timur Tahun 2016. Samarinda:Perwakilan BPKP Provinsi Kalimantan Timur.

Hiro Tugiman.2006. Standar Profesional Audit Internal. Yogyakarta: Universitas Kanisius

Mulyadi. 2010. Auditing: Buku 1 Edisi 6. Jakarta: Salemba Empat.

Suroso. 2010. Auditing dan Akuntansi serta Hubungannya. Jurnal Akuntansi Bisnis dan Publik Program 
Studi Akuntansi. Vol. I No. 1 Desember. Medan: Universitas

Pembangunan Panca Budi 